\title{
NORTH AMERICAN ECONOMIC INTEGRATION
}

\author{
MORDECHAI E. KREININ*
}

\section{I \\ THE IDEA OF INTEGRATION}

Economic integration of the three North American countries, Canada, Mexico and the United States, is not an entirely new idea. Particularly in Canada there has been a long standing interest in, and controversy about, closer economic ties wth the United States. In the automotive industry free trade has already been established between the two countries. This is not surprising, given the fact that each of the two countries is the most important trading partner of the other. Adding Mexico to the equation is more novel. But even here one may note the large scale mobility of labor from Mexico to the United States (both legal and illegal) and the considerable flow of investment capital from the United States to its southern neighbor.

Yet formal integration of the three countries must still be considered an idea whose time has not arrived. Political, economic and even emotional animosities in Mexico towards the United States are all too well known. Even in Canada there is widespread fear that with integration "Canadians will become hewers of wood and drawers of water." In both cases there is a rational or irrational fear of the economic giant across the border. Integration in other parts of the world has usually occurred among countries smaller and more equal in size and economic development than would be the case in North America.

However, the future may bring fresh impetus to integration. Increased military, political and economic pressures around the globe may drive the three countries closer together (although, admittedly, it may also pull them apart). The discovery of new energy sources in Mexico, Alaska (which is separated by Canada from the "lower" 48 states) and Canada, may dictate closer cooperation in investments, production and consumption in decades of increasing energy scarcity. The same may be said about other primary commodities. Migration pressure of Mexican workers may also dictate closer cooperation. Paradoxical as it may seem, pressure for secession in Quebec province may drive the Western and "far eastern" provinces of Canada to form closer economic ties with the United States.

In a more general way, exploration of ideas often precedes political action by

\footnotetext{
Copyright (c) 1981 by Law and Contemporary Problems.

*Professor of Economics, Michigan State University

1. See R. Wonnacott \& P. Wonnacott, Free trade Between the United States and CaNada: The Potential Economic Effects, at $u i$ (1967) (hereinafter cited as WonnacotT \& WonNACOTT].
} 
years or even decades. Hence it is not premature to examine the feasibility and the impact of North American integration.

\section{ECONOMiC Integration Generally}

\section{A. Introduction}

Almost any formal measure of economic integration would strengthen the ties between the three countries, cause an adjustment to new circumstances within each of the three economies, call for some surrender of national sovereignty in a specified area of economic policy, and probably discriminate against outsiders. Factors affecting the decision to adopt integration measures include limitations imposed by prior international agreement as well as the effects of underlying economic principles. This section will discuss the international trade rules and the economic considerations involved in a North American integration policy.

\section{B. The Effect of GATT}

The United States and Canada (but not Mexico) are members of the Genevabased organization, the General Agreement on Tariffs and Trade (GATT) and must abide by its rules. ${ }^{2}$ For example, GATT rules forbid such conduct as dumping and governmental imposition of export subsidies. They also permit an importing country receiving "dumped" commodities to levy countervailing duty against them.

1. The GATT MFN rule. One important and long standing rule is a principle of nondiscrimination in international trade. Under it, a country must apply the same import duty on a given product to the exports of all GATT members supplying that product. All sources of supply of a given product are charged the same duty, provided that they are members of GATT. Equivalently, any tariff reduction on a commodity must apply to all GATT members supplying that commodity. This is known as the Most Favored Nation (MFN) principle. ${ }^{3}$

This rule has been violated on many occasions by countries on both sides of the Atlantic. ${ }^{4}$ In the case of North America, the Canadian-U.S. Automobile

2. GATT - The General Agreement on Tariffs and Trade-is a multilateral treaty, subscribed to by over ninety governments which together account for more than four fifths of world trade. Its basic aim is to liberalize world trade, and place it on a secure basis, thereby contributing to economic growth and development and the welfare of the world's peoples. The General Agreement is the only multilateral instrument that lays down agreed-upon rules for international trade.

The Geneva based organization was established in 1948. For thirty years, GATT has also functioned as the principal international body concerned with negotiating the reduction of trade barriers and with international trade relations. GATT is thus both a code of rules and a form in which countries can discuss and overcome their trade problems and negotiate to enlarge world trading opportunities.

For details see the short pamphlet GATT, GATT, WHAT IT IS; WHAT IT DOES (1977). Once a year GATT publishes a pamphlet describing its activities, the latest being GATT, GATT ACTIVITIES, 1980 (1981) as well as a pamphlet analyzing world trade developments during the year, the latest being GATT, INTERNATIONAL TRADE 1980/81 (1981).

3. GATT, GATT, WHAT IT Is; WHAT IT DOES, supra note 2, at 2.

4. M. Kreinin, International Economics-A Policy Approach 355 (3d ed. 1979) [hereinafter cited as Kreinin]. See also GATT, GATT AĆtivities (published annually). 
Agreement, ${ }^{5}$ which freed trade in automobiles and parts between the two countries, discriminates against European and Japanese producers, and is thus in violation of the MFN rule. GATT regulations require a waiver for any deviations from the rule. ${ }^{6}$ While often the countries involved failed to seek such a waiver, good international conduct dictates compliance with the principle. Otherwise, the smoothly functioning international trading system among the industrial countries could be in jeopardy.

2. Exceptions to the MFN Rule Governing LDCs Trade. During the past decade a general waiver has been granted for the exports of the developing countries (otherwise known as Less Developed Countries or LDCs). ${ }^{7}$ To accommodate this general system of preferences (GSP), industrial countries are permitted to grant favored treatment to imports from the LDCs over imports from other industrial countries. Under the U.S. and Canadian GSP, LDCs' exports of manufactured products enter the two countries duty free. This treatment applies to Mexican exports as well, but there are several limitations on the type and quantity of imports that are accorded this beneficial treatment. As a result of these restrictions, the benefits to LDCs' exports, including those of Mexico, are very limited.

Much more beneficial to Mexico is U.S. tariff item 807.00.8 Under it, a company can use U.S. materials in its foreign plants, subject them to further fabrication abroad, reimport them to the United States for further (perhaps final) processing, and pay duty only on the value added abroad.

To illustrate the point, assume that four stages are needed to manufacture a certain product (e.g., raw wood-lumber-semifinished desk-finished desk). At each stage a value of $\$ 100$ is added, for a total price of $\$ 400$ for the final product. Assume that the first two stages are done in the United States, and the resulting semiprocessed good, worth $\$ 200$, is shipped to Mexico for third stage fabrication. The resulting semifinished product, worth $\$ 300$, is then reimported into the United States for final processing. Although that import is worth $\$ 300$, the duty is levied only on the $\$ 100$ value added in Mexico-quite a considerable saving. Mexican law, in turn, permits the importation of the semiprocessed good (worth $\$ 200$ ) free of Mexican duty, creating a free trade zone in order to further encourage processing inside Mexico. ${ }^{9}$

Hundreds of American plants, set up just south of the border, owe their existence largely to this provision. They take advantage of lower labor costs in Mexico, and at the same time provide employment to Mexican workers. This system is

5. KREININ, supra note 4 .

6. GATT, GATT, What IT Is, What IT DOEs, supra note 2, at 3; GATT, GATT Activities (published annually).

7. GATT, GATT, What IT Is, WhAT IT DOEs, supra note 2, at 13-15; KREININ, supra note 4, at ch 17.

8. Finger, Trade and Domestic Effects of the Offshore Assembly Provision in the U.S. Tariff, 66 AM. ECON. REV 598 (1976); Finger, Tariff Provisions for Offshore Assembly and the Exports of Developing Countries, 85 ECON. J. 365 (1975). See also Kreinin and Finger, A Critical Review of the New International Economic Order, J. WORLD Trade L. (Nov./Dec. 1976).

9. KREININ, supra note 4 , at ch. 17. 
estimated to have stimulated much more LDC exports than the GSP. ${ }^{10}$ Such U.S. investments in Mexico would certainly be encouraged if the U.S. tariff on imports from Mexico were eliminated altogether.

But the preferences outlined above are generally a one-way street, favoring the LDCs. They apply to the treatment of Mexican exports in the United States and Canada, but not to U.S. and Canadian exports in Mexico. Regional integration must involve a two-way favored treatment.

3. General Exceptions to the MFN Rule. To accommodate regional integration schemes, the GATT MFN rule has a couple of general exceptions. Besides a grandfather clause that allows tariff preference between a "mother country" and its former colonies, GATT rules permit the establishment of (i) free trade areas, and (ii) customs unions. ${ }^{11}$

A customs union involves two or more countries that abolish all trade restrictions among themselves and set up a common and uniform tariff against outsiders, known as the common external tariff. The level of that tariff is set by the member states, and becomes the measure of discrimination against outsiders, or the margin of preference in favor of members. Members of the customs union pay no duty while outsiders are subject to the common external tariff. A free trade area (FTA) also involves the abolition of trade restriction among the integrating countries. But, in contrast to a customs union, each country retains its own tariff rates against nonmembers, so that there is no common external tariff. The margin of discrimination against outsiders varies from one member to another and equals each country's tariff: nonmembers pay the tariff, while members of the FTA export duty free within the area.

To qualify for either of the two exceptions to the MFN rule, all or most of the trade restrictions within the area must be removed; and the tariff levied on imports from nonmembers must be no higher than the average rates prevailing prior to integration. ${ }^{12}$ In the case of a customs union this means that the common external tariff may not exceed the weighted average of the individual countries' tariffs.

Numerous regional integration schemes fall under one of these two categories. The European Communities of nine members, and the European Free Trade Association of six small countries, are illustrations of a customs union and FTA, respectively, in Europe. The Central American Common Market is a customs union of five countries in Central America. African countries have formed such regional groupings, and negotiations for similar units are being held in Asia. Finally, the Latin American Free Trade Area (LAFTA) is an FTA encompassing seven major Latin American countries, including Mexico. In other words, Mexico is already a member of an FTA with Brazil, Argentina, Chile, Colombia, Ecuador and Venezuela.

A regional grouping may of course proceed further in the integration process than the mere freeing of trade. For example, it may allow free flow of investment

10. See note 8 supra.

11. KreININ, supra note 4, at ch. 16; GATT, GATT, What It Is, What It Does, supra note 2, at 5.

12. Id. 
and other capital, and/or full labor mobility between member countries. It may have a common agricultural policy, coordinate domestic fiscal and monetary policies, and even proceed in the direction of monetary integration toward a common currency. The further the progress toward integration, the greater the surrender of national sovereignty on the part of member countries.

\section{The Economics of Regional Integration}

1. Static Effects. The body of economic analysis dealing with regional integration, dating back to the work of Jacob Viner and James Meade, ${ }^{13}$ is concerned mainly with the effect of a regional grouping on worldwide economic efficiency and allocation of resources. It has become traditional to distinguish two contrasting effects: a favorable trade creation and an unfavorable trade diversion. Because they are concerned with reorganization of production with a given amount of resources, these are known as static effects.

Consider a three-country world in which countries A and B form a customs union to the exclusion of $\mathrm{C}$. Three effects on the world economy will occur. First, with respect to products in which $\mathrm{A}$ and $\mathrm{B}$ are competitive, the elimination of tariffs between them causes the replacement of some high-cost production by imports from the partner country. This effect, known as "trade creation," is favorable to welfare because it rationally reorganizes production within the union. Second, for products in which country $\mathrm{C}$ is competitive with one of the integrating countries, A or B begins to import from the other what it earlier imported from $\mathrm{C}$. If $\mathrm{C}$ is the most efficient producer, it will be the major supplier as long as its products receive the same tariff treatment as those of its competitor. The tariff discrimination, however, induces diversion of trade away from $\mathrm{C}$ toward a member country. This effect, known as "trade diversion," is unfavorable, because it reorganizes world production less efficiently. Production shifts from the most efficient locations in $\mathrm{C}$ to less efficient ones inside the union. Finally, there is a favorable consumption effect, as consumers in each member state benefit from price reduction on imports from the partner country when intraunion tariffs are removed. It is usually lumped together with trade creation. ${ }^{14}$

In order to measure the magnitude of these effects empirically, one must first isolate the effect of integration on trade flows. Over any given time period there is a multitude of factors that affect these flows. Foremost among them are changes in real income and changes in each country's competitive position (relative prices). The influence of these and other factors on trade flows need to be "removed" so that only the effect of integration remains.

Once the effect of these extraneous factors is removed, the measure of the two integration effects is as follows: (i) trade creation is the diminution of domestic output inside the integrating countries A or B, it being replaced by cheaper imports from the partner country; and (ii) trade diversion is the diminution of the

13. J. Viner, The Customs Union Issue ch. 4 (1950); J. Mende, The Theory of Customs UnIONS (1955).

14. We overlook another less important effect. The "terms of trade" of the integrating area are likely to improve at the expense of the rest of the world. 
customs union's imports from country $\mathrm{C}$, known as external imports, it being replaced by imports from within the customs union. The increase in intraunion trade is trade creation and diversion combined. Thus the increase in country A's imports from B is partly at the expense of A's output (trade creation) and partly at the expense of C's exports (trade diversion).

In the case of the European communities, empirical studies have shown trade creation to be five to seven times greater than trade diversion. ${ }^{15}$ Various studies also demonstrated that the vast expansion of intra-European trade took the form of intraindustry rather than interindustry specialization. ${ }^{16}$ There has been no large scale contraction of entire industries in any one country as their products are replaced by imports from another member. Rather, the same industries in various member countries moved to specialize in specific types of subproducts. This eases the adjustment to freer trade, since labor and capital need not be moved between industries. Increased intraindustry specialization is characteristic of trade flows among industrial countries.

2. Dynamic Effects. Equally important, although far less tangible, are the dynamic effects of integration. The nonreversible removal of trade barriers in a customs union or FTA creates a far wider market than that of each individual country. This enables firms to exploit economies of scale in production and distribution activities, increases competition between firms since the expanded market can support more sizeable firms in each industry, and encourages investments by both domestic and foreign companies. All these influences promote faster growth in real GNP and place the integrating region on a higher growth trajectory. The smaller the integrating countries are, the more important these effects are likely to be.

In the case of North America, while the United States is large enough to enjoy all the benefits of scale even without integration, Canada and Mexico are not. These countries could draw considerable benefits from expanded market size and from the stimulus to investments associated with integration. Certainly investments in Mexico would expand if the product of such plants could enter the U.S. market duty free.

3. Issues Concerning LDCs. The concepts outlined above cannot be directly applied to all cases, especially where LDCs are involved. Where there is little industrial base, integration may benefit a country's industrialization policy. A country intent on industrializing via a strategy of import substitution, or replacing imports with new domestic production under the umbrella of a heavily protective import regime, may pursue that strategy more efficiently in the combined market of several countries than in the minute individual market of each country.

Also, where no industrial base exists prior to integration, no trade creation can

15. Kreinin, Effects of the EEC on Imports of Manufactures, 82 EcON. J. 897 (1972); Kreinin, Effect of EC Enlargement on Trade in Manufactures, 34 KYKLOS 1 (1981).

16. Kreinin, Effect of EC Enlargement on Trade in Manufactures, 34 KyKLOS app. (1981); Balassa, Tariff Reductions and Trade in Manufactures, 56 AM. ECON. REv. 466 (1966). 
be expected. In this case, trade diversion may be beneficial. The harm of trade diversion is rooted in the reallocation of productive resources, such as labor, from more to less efficient uses; if the resources are unemployed from the outset, no harm is caused. In many LDCs, there is much disguised and overt unemployment. ${ }^{17}$ If trade diversion provides employment to otherwise unemployed resources, it may be beneficial.

Another special consideration regarding LDCs relates to the countries' economic base. When one nation starts from a more advanced base than the rest of the integrated area, it is likely to attract many incipient industries in anticipation of supplying the entire customs union. This phenomenon is known as polarization. It suggests an uneven distribution of the benefits from integration. Special provisions must be made to minimize this effect, lest some of the countries grow increasingly dissatisfied.

These considerations suggest that the standard anlysis of integration cannot be applied.blindly to a grouping such as North America which includes countries at vastly different stages of economic development.

4. Applications to the North American Grouping. The amount of trade creation and diversion likely to occur in an integration situation depends on the size of the area, the amount of intra-area trade, the character and costs of production in each country, and tariff protection against nonmembers. It is possible to speculate on the criteria that determine the size of trade creation and diversion as they apply to a North American economic grouping.

First, the larger the economic size of the integrating area is, the greater the likelihood of trade creation and the smaller the probability of trade diversion. At the extreme, an FTA encompassing the entire globe can cause only trade creation. With North America accounting for 28 percent of worldwide GNP, trade creation is likely to be relatively large.

Second, the greater the share of intra-area trade in the countries' total trade prior to integration, the greater is the scope for trade creation and the smaller the scope for trade diversion. Table 4 shows that over two thirds of Canada's and Mexico's trade is with their North American partners. For the United States the respective share is one quarter. This suggests that trade creation is likely to be much larger than trade diversion.

Third, the more similar the type of products produced by the integrating economies, the more likely they are to displace each other's output in products in which each, respectively, has a comparative advantage, and the greater the likelihood of trade creation. Conversely, the more dissimilar and complementary the output, the greater the likelihood of trade diversion. One may therefore expect considerable trade diversion to occur in the case of North American integration; however, this result is mitigated by considerations outlined below. ${ }^{18}$

A fourth criterion is the size of production cost differentials between the three

17. Kreinin, supra note 4, at ch. 17; ECONOMiC InTegration in Central America (W. Cline \& E. Delgado eds. 1978).

18. See the discussion at $30-31$ infra. 
countries in each of the various industries. The larger the differential, the greater the scope for displacement of output in one country by that of another member once protection is removed, since protection makes possible the maintenance of such differentials. On that criterion one can expect large trade creation in the case of North American integration.

Next, the higher the level of tariff protection against imports from nonmembers, the higher the scope for trade diversion. In the case of North America, medium level protection can be expected, leaving some scope for trade diversion. Finally, the commodity composition of the trade between the three members is such that sizeable trade creation can be anticipated.

In sum, while both trade creation and diversion can be expected to result from North American integration, a conjecture is that trade creation is likely to be larger.

III

INTEGRATION IN NORTH AMERICA

\section{A. Alternative Modes for North American Integration}

Some special economic ties already exist between the three North American countries. They include: the U.S.-Canada automobile agreement covering autos and parts; a reasonably integrated market for capital between New York, Montreal and Toronto; U.S. tariff item 807.00, of which Mexico is one main beneficiary; general flow of investment capital from the United States to Canada and Mexico; the U.S. and Canadian GSP which benefits Mexico (along with other LDCs) to a limited degree; and the migration of labor from Mexico to the United States. The development of oil and natural gas resources in Mexico is likely to strengthen economic ties, as geographical proximity makes the United States the natural market for these products. The concern of this article, however, is with the establishment of more formal ties.

1. A Customs Union. Because it requires a common external tariff, a customs union is not a realistic possibility for North American integration, and should not even be contemplated. Not only is the level of the Mexican tariff double that of its U.S. counterpart, but the structure (i.e., differences in rates imposed on different products) is also different. Canadian rates generally fall between the two. ${ }^{19}$ It would be nearly impossible to negotiate a common external tariff. Besides, a customs union could not accommodate Mexico's membership in LAFTA. For these reasons an FTA in manufactured products is the only feasible alternative.

2. A Free Trade Area. The lowest form of formal regional grouping appropriate for the three North American countries is a free trade area in manufactured

19. Balassa, Tariff Protection in Industrial Countries: An Evaluation, 73 J. Pol. EcoN. 27 (Dec. 1965); B. Balassa, The Structure of Protection in Developing Countries (1971). See also Wonnacott \& WONNACOTT, supra note 1 , at ch. 12. 
products. Not requiring a common external tariff, it avoids the need for compromise on this thorny issue between countries of vastly different tariff levels and foreign trade objectives and obligations. Thus Mexico can remain a member of LAFTA, admitting imports from other Latin American members duty free. On imports from other continents, the Mexican tariff rates can remain a multiple of its U.S. counterpart. In turn, the United States and Canada may continue any special import regimes with respect to imports from other continents, such as the GSP or U.S. tariff item 807.00 .

An FTA calls for promulgation and enforcement of "rules of origin" to avoid transshipment of external imports into one member state through another. ${ }^{20}$ For example, if the Mexican duty on bicycles is 40 percent while the U.S. duty is only 10 percent, British bikes can be shipped to the United States at the lower tariff, and then move duty free into Mexico. Border check points to ascertain the true origin of goods are not sufficient. The British producer can bypass them by superficial fabrication in the United States, adding only finishing touches to the bike that was actually produced in Britain. For that reason an FTA needs to spell out what proportion of the value of a product must be produced within the area for it to be accorded duty free status. In the case of the European Free Trade Association, that proportion is one-half. ${ }^{21}$ While this adds administrative complexity, it is not an insurmountable obstacle.

Although it is a relatively loose organization an FTA requires the surrender of some measure of national sovereignty. Each country relinquishes the right to impose trade restrictions on its imports from the partner countries.

Because the internal adjustment problems may be severe in certain industries and locations, political resistance to an FTA is likely to be strong. At best tariff reductions among the three members would have to be staged over a period of at least a decade. Since this FTA encompasses two fully industrialized countries and one semi-industrialized country, Mexico would require a much longer transitional period.

3. Other Measures. What of steps going beyond the freeing of trade? A common labor pool, which would imply free labor mobility, is unrealistic to contemplate. Given the huge differential in wage rates between the United States and Mexico, it would be far too unsettling to labor markets. But some ad hoc measures to regulate labor movement can be negotiated. It should be noted that the freeing of trade may remove some of the incentives for Mexican workers to migrate to the United States. Ad hoc measures to stimulate capital movements can also be negotiated.

A common currency, or a significant move toward immutably fixed exchange rates, is also out of the question at this time. The Canadian dollar is a floating currency; it fluctuates daily against the U.S. dollar in response to supply and demand conditions. While the Mexican peso has been de facto fixed at 4.1 cents for the past several years, the Mexican government can change the rate (devalue or

20. KREININ, supra note 4 , at $\mathrm{ch} .16$.

21. Id. 
revalue the peso) as circumstances warrant. ${ }^{22}$ Under immutably fixed exchange rates each country must relinquish its right to change the value of its currency, a very unlikely occurrence. Such a regime requires a high measure of coordination of domestic fiscal and monetary policies, and the constituent countries would not be willing to surrender sovereignty in these matters. There might even be fears in Canada and Mexico that under such an arrangement their monetary policies would be decided in Washington. Last, and most emphatically, the very introduction of free trade would call for certain exchange rate adjustments to balance the external accounts.

In sum, the only formal agreement that is reasonable to consider is a free trade area in manufactured products, to be put into effect in small steps over a very long transitional period.

\section{B. Structure of the Three Economies}

An FTA in North America would be unprecedented in at least two important respects. First, it would incorporate two industrial countries (the United States and Canada) and one developing country (Mexico). All other integration schemes in the world involve customs unions or FTAs among countries at equal stages of development, either industrialized or developing. Second, the U.S. economy dominates the region to a degree unfound in other regional groupings, being ten times the size of Canada and twenty-two times that of Mexico. These features are likely to pose difficulties in the integration process. The extent of the countries' socio-economic disparity is illustrated in Table I. The GNP and per capita GNP

\section{TABLE 1}

\section{General Characteristics of the Three Economies}

\section{9}

$\overline{\text { Area }}$ (square kilometers)

Population (millions)

GNP (billions of U.S. dollars)

GNP per capita (U.S. dollars)

Adult literacy

Life expectancy at birth

Annual Growth Rates (\%)

Population (1970-1978)

GNP per capita (1970-1978)

GNP per capita (1960-1979)

Average annual rate of inflation (1960-1970)

Average annual rate of inflation (1970-1979)

Currency:

$\overline{\text { July } 1981}$ exchange rates

\begin{tabular}{|c|c|c|}
\hline U.S.A. & Canada & Mexico \\
\hline 9,363 & 9,976 & 1,973 \\
\hline 224 & 24 & 65 \\
\hline 2,377 & 228 & 108 \\
\hline 10,820 & 9,650 & 1,590 \\
\hline $99 \%$ & $99 \%$ & $82 \%$ \\
\hline 74 & 74 & 66 \\
\hline
\end{tabular}

$\begin{array}{llr}0.8 \% & 1.3 \% & 3.3 \% \\ 2.3 \% & 3.0 \% & 1.3 \% \\ 2.4 \% & 3.5 \% & 2.7 \% \\ 2.8 \% & 3.1 \% & 3.6 \% \\ 6.9 \% & 9.1 \% & 18.3 \%\end{array}$

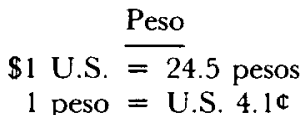

Sources: Worl.d Bank Ati.as, (1980); World Bank, Worl.d Development Report (1981); Fed. Res. Bull. A66 (Aug. 1981).

22. For Exchange Rate arrangements of various countries see the Supplement on the Fund, IMF SURVEY 6-7 (May 1981). 
TABLE 2

Structure of the Three Economies

\begin{tabular}{|c|c|c|c|c|c|c|}
\hline & \multicolumn{2}{|c|}{ U.S.A. } & \multicolumn{2}{|c|}{ Canada } & \multicolumn{2}{|c|}{ Mexico } \\
\hline & 1960 & 1979 & 1960 & 1979 & 1960 & 1979 \\
\hline Distribution $\mathrm{c}$ & Force & & & & & \\
\hline Agriculture & $7 \%$ & $2 \%$ & $13 \%$ & $5 \%$ & $55 \%$ & $37 \%$ \\
\hline Industry & 36 & 32 & 35 & 29 & 20 & 26 \\
\hline Services & 57 & 66 & 52 & 66 & 25 & 37 \\
\hline
\end{tabular}

B. Distribution of Gross Domestic Product (\%)

\begin{tabular}{|c|c|c|c|c|c|}
\hline Agriculture & $4 \%$ & $3 \%$ & $6 \%$ & $4 \%$ & $16 \%$ \\
\hline Industry & 38 & 34 & 34 & 33 & 29 \\
\hline Services & 58 & 63 & 60 & 63 & 55 \\
\hline
\end{tabular}

C. Detailed Distribution of Gross Domestic Product (\%)

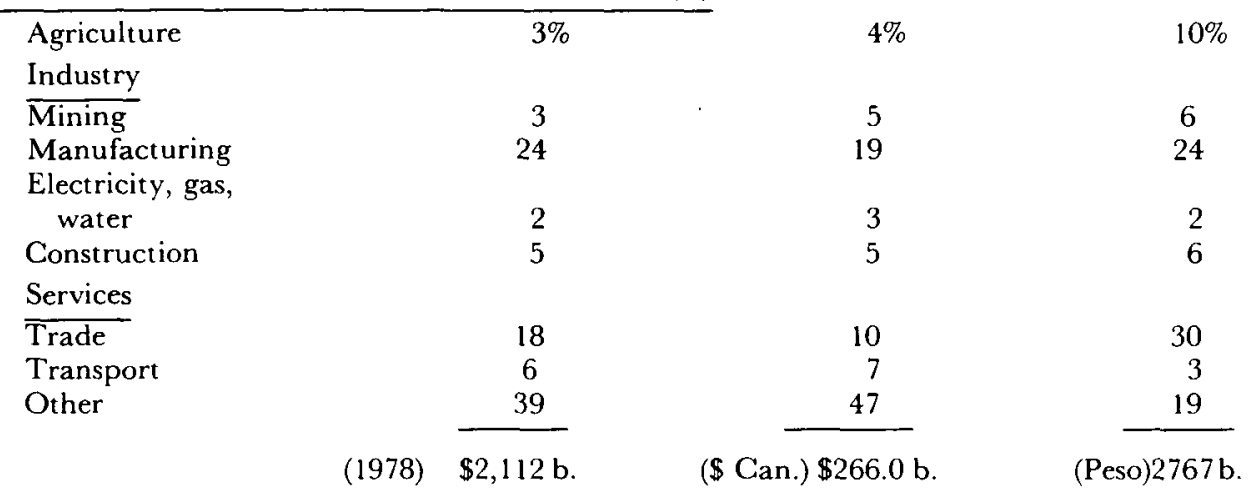

D. Energy Consumption (kg. of coal equivalent)

$\begin{array}{lrrrrrr}\begin{array}{l}\text { Per capita } \\ \text { Per dollar of GDP }\end{array} & 8,228 & 12,350 & 7,087 & 13,453 & 769 & 1,673 \\ \quad(1960 \text { and 1978) } & 1.6 & 1.4 & 1.3 & 1.3 & 0.9 & 1.0\end{array}$

E. Value Added in Manufacturing (1978)

\begin{tabular}{|c|c|c|c|}
\hline Food & $11 \%$ & $13 \%$ & $22 \%$ \\
\hline Textile and clothing & 6 & 7 & 11 \\
\hline \multicolumn{4}{|l|}{$\begin{array}{l}\text { Machinery and } \\
\text { transport }\end{array}$} \\
\hline equipment & 32 & 23 & 17 \\
\hline Chemicals & 11 & 8 & 14 \\
\hline Other manufactures & 40 & 49 & 36 \\
\hline $\begin{array}{l}\text { TOTAL, Billions } \\
\text { of } 1975 \text { Dollars }\end{array}$ & 434 & 37 & 25 \\
\hline \multicolumn{4}{|c|}{ Structure of Demand (1979) } \\
\hline Private consumption & $62 \%$ & $56 \%$ & $64 \%$ \\
\hline Public consumption & 12 & 19 & 18 \\
\hline Gross domestic & & & \\
\hline investments & 28 & 24 & 19 \\
\hline Exports of goods & & & \\
\hline $\begin{array}{l}\text { and services } \\
\text { Gross domestic }\end{array}$ & 12 & 28 & 9 \\
\hline $\begin{array}{l}\text { Gross domestic } \\
\text { saving }\end{array}$ & 26 & 25 & 18 \\
\hline
\end{tabular}

Sources: 33 U.N. Monthly Bulletin of Statistics (No. 5), U.N. Doc. ST/ESA/STAT/SER.Q 177 (May 1981); WORI.D Bank, WORL.D Development RepOrt (1981). 
give a broad measure of a country's economic performance and standard of living respectively. These and other social factors such as literacy and life expectancy show Mexican development to be far behind its neighbors to the north.

Table 2 highlights the structure of the three economies. Panels A and B show that all three countries experienced a decline, between 1960 and 1979, in the share of the labor force and of output devoted to the agricultural sector. While the compensating increase in the United States and Canada was in services, in Mexico it was mainly in industry. In 1979 two thirds of the economic activity in the United States and Canada was in services compared to only one half in Mexico. It is a reflection of the differential productivity and stage of development that a full third of the Mexican labor force is still employed in agriculture, compared to 3 percent in the United States. These differentials are even more striking in Panel C, which shows a detailed distribution of Gross Domestic Product (GDP) in 1979. The figures are self-explanatory, and they reflect the differential stages of development of the three countries.

A similar indicator, per capita energy consumption (Panel D), may be viewed as a proxy for the degree of mechanization in the economy. It is far smaller in Mexico than in its two neighbors to the north. (The decline in the U.S. energy consumption per GDP between 1960 and 1979 reflects an increase in energy efficiency triggered by the rise in energy prices in this country.)

Within the manufacturing sector (Panel E), capital intensive and technologically sophisticated goods, such as machinery and transport equipment, are paramount in the United States. Labor intensive and relatively unsophisticated products, such as textiles, clothing, and food products, occupy a large share of Mexico's output. Panel $F$ shows the distribution of final demand.

Mexican development since 1977 has been dominated by the discovery of large oil wealth. Oil output rose from under one million barrels per day in 1976 to over two million in 1980. A commensurate increase took place in the production of natural gas. Coupled with the twelve-fold increase in international oil prices over the last seven years to $\$ 32$ per barrel (at home Mexican oil is still priced at $\$ 8.50$ per barrel), ${ }^{23}$ the rise in output brought in a huge increase in oil revenue.

While there is intense domestic and foreign pressure on Mexico to boost its oil output faster, the government appears intent on a go-slow policy producing just enough to meet the needs of the economic development plan. ${ }^{24}$ The announced government plan is to use the oil wealth to build a new industrial foundation, gradually turning a finite resource into a permanent source of wealth. An FTA with the United States and Canada can help in that endeavor.

\section{Structure of Foreign Trade}

1. Production Structure. The differential structure of production is reflected in the structure of trade, as shown in Table 3.

23. Seib, Will Lopez Portillo Stick to His Oil Plan?', Wall St. J., Feb. 7, 1980, at 4, col.1.

24. Id. 
TABLE 3

\section{Structure of Three Countries' Trade}

(A) Percentage Distribution of Exports (X) and Imports (M) Among Commodities

\begin{tabular}{|c|c|c|c|c|c|c|}
\hline \multirow[b]{3}{*}{ Total (Sbillions) } & \multicolumn{2}{|c|}{ USA (1979) } & \multicolumn{2}{|c|}{ Canada (1979) } & \multicolumn{2}{|c|}{ Mexico (1977) } \\
\hline & $\bar{x}$ & $\bar{M}$ & $\mathrm{x}$ & $\mathbf{M}$ & $\mathrm{x}$ & $\mathbf{M}$ \\
\hline & $17 \overline{3.6}$ & $21 \overline{7.5}$ & $55 . \overline{1}$ & 52.6 & $4 . \overline{2}$ & $5 . \overline{6}$ \\
\hline \multicolumn{7}{|l|}{ Percentage Distribution (\%) } \\
\hline Food & $18.9 \%$ & $9.2 \%$ & $11.4 \%$ & $7.3 \%$ & $33.8 \%$ & $13.1 \%$ \\
\hline Agricultural raw materials & 5.5 & 3.2 & 12.1 & 2.5 & 5.4 & 3.8 \\
\hline Fuels & 3.2 & 29.3 & 13.2 & 9.3 & 21.9 & 3.0 \\
\hline Ores and metals & 5.3 & 8.5 & 14.8 & 6.2 & 12.7 & 8.6 \\
\hline Manufactures & 64.7 & 48.3 & 48.2 & 73.4 & 26.2 & 71.6 \\
\hline Chemicals & 10.8 & 3.9 & 5.7 & 6.3 & 6.5 & 15.1 \\
\hline Non-electrical machinery & 18.4 & 7.0 & 8.2 & 18.5 & 2.7 & 21.4 \\
\hline Electrical machinery & 8.1 & 6.0 & 2.5 & 6.1 & 1.7 & 8.5 \\
\hline Transport equipment & 14.7 & 12.5 & 19.4 & 24.6 & 1.5 & 15.4 \\
\hline Textiles and clothing & 4.1 & 4.0 & 0.9 & 4.4 & 8.0 & 1.6 \\
\hline
\end{tabular}

(B) Major Exports of Each Country (1977)

Commodity

All commodities

Road motor vehicles

Machines nes, nonelectric

Aircraft

Oil seeds, nuts, kernels

Electrical machinery

Maize, unmilled

Office machines

Power machinery non-elec.

Specialized machinery nes

Organic chemicals

Coal, coke, briquettes

Wheat, unmilled

Electrical power machines

Instruments, apparatus

Telecommunications equipments

Remainder

\begin{tabular}{|c|c|}
\hline \multicolumn{2}{|c|}{ United States } \\
\hline Value (\$billions) & Percent of U.S. Total X \\
\hline$\$ 117.9$ & $100.0 \%$ \\
\hline 11.8 & 10.0 \\
\hline 8.4 & 2.1 \\
\hline 5.9 & 5.0 \\
\hline 4.8 & 4.1 \\
\hline 4.6 & 3.9 \\
\hline 4.1 & 3.5 \\
\hline 3.6 & 3.1 \\
\hline 3.6 & 3.1 \\
\hline 3.6 & 3.0 \\
\hline 3.2 & 2.7 \\
\hline 2.7 & 2.3 \\
\hline 2.7 & 2.3 \\
\hline 2.3 & 2.0 \\
\hline 2.2 & 1.9 \\
\hline 2.1 & 1.8 \\
\hline 52.2 & 44.3 \\
\hline
\end{tabular}


Commodity

All commodities

Road motor vehicles

Paper and paperboard

Gas, natural and manufactured

Wood, shaped

Pulp and wastepaper

Wheat, etc., unmilled

Crude petroleum, etc.

Power machinery, nonelectric

Nonferrous metals

Iron ore, concentrates

Aluminum

Machines nes nonelectric

Fish

Other crude minerals

Fertilizers

Remainder

Commodity

All commodities

Crude petroleum, etc.

Coffee

Veg., etc., fresh, simply prsvd.

Cotton

Fish fresh, simply prsvd.

Silver, platinum etc.

Inorg. elements, oxides, etc.

Fruit, preserved, prepared

Live animals

Other crude minerals

Zinc

Textile yarn and thread

Road motor vehicles

Nonferrous base metals

Sulphur etc.

Remainder

\begin{tabular}{|c|c|}
\hline & Canada \\
\hline Value (\$billions) & Percent of Total X \\
\hline$\$ 41.3$ & $100.0 \%$ \\
\hline 8.8 & 21.3 \\
\hline 2.6 & 6.4 \\
\hline 2.3 & 5.6 \\
\hline 2.3 & 5.8 \\
\hline 2.0 & 5.0 \\
\hline 1.7 & 4.2 \\
\hline 1.6 & 4.0 \\
\hline 1.3 & 3.2 \\
\hline 1.2 & 2.9 \\
\hline 1.0 & 2.4 \\
\hline 0.7 & 1.7 \\
\hline 0.7 & 1.6 \\
\hline 0.7 & 1.6 \\
\hline 0.6 & 1.5 \\
\hline 0.6 & 1.5 \\
\hline 13.0 & 31.6 \\
\hline
\end{tabular}

\begin{tabular}{|c|c|}
\hline \multirow[b]{2}{*}{ Value (\$billions) } & \multirow{2}{*}{$\frac{\mathrm{co}}{\text { Percent of Total } \mathrm{X}}$} \\
\hline & \\
\hline$\$ 4.2$ & 100.0 \\
\hline 0.9 & 21.3 \\
\hline 0.5 & 11.5 \\
\hline 0.3 & 7.5 \\
\hline 0.2 & 4.4 \\
\hline 0.2 & 4.3 \\
\hline 0.1 & 2.5 \\
\hline 0.1 & 1.9 \\
\hline 0.1 & 1.9 \\
\hline 0.1 & 1.8 \\
\hline 0.1 & 1.6 \\
\hline 0.1 & 1.6 \\
\hline 0.1 & 1.5 \\
\hline 0.05 & 1.3 \\
\hline 0.05 & 1.2 \\
\hline 0.05 & 1.2 \\
\hline 1.5 & 34.6 \\
\hline
\end{tabular}

Source: UNCTAD, Handbook of International Trade and Development Statistics, Supplement 110 , 120, 150, 166, 167, 178, 187, U.N. Doc. TD/STAT. 9 (1980).

Food exports are proportionately most important in Mexico, followed by fuels (a rather recent development). While the United States is a large net importer of fuels, Canada and especially Mexico are net exporters. However, Mexico exports mainly crude petroleum, and is a net importer of petroleum products. Manufacturing exports are proportionately most important in the United States and least important in Mexico, and of median importance in Canada. Canada, and more so Mexico, are net importers of manufactured products. Within the manufacturing sector, Mexican exports are heavily concentrated in textiles and clothing, as well as other labor intensive products. U.S. exports (and to a lesser extent those of Canada), are centered in capital intensive and technologically sophisticated items, which in turn form the bulk of Mexican manufacturing imports. Agricultural products and high technology items loom important in U.S. exports. By contrast, 
Mexican exports are heavily weighted with food, agricultural or raw materialbased items, and labor intensive goods. Canada exports mainly grains, materials and material-based products (i.e., paper and pulp) and technologically sophisticated commodities.

These figures conform well to theoretical expectations. The neo-factor proportion theory of international trade-which dates back to the work of the Swedish economists Heckescher and Ohlin-explains the commodity composition of trade as a marriage between (a) the relative factor endozment of the countries and (b) the relative factor intensity of the products. ${ }^{25}$ Each country will produce the product that uses intensely its relatively abundant and cheap factor of production. In a relatively labor abundant country such as Mexico, goods and production processes utilizing a lower capital-to-labor ratio will be chosen, while in relatively capital abundant countries such as the United States, goods and processes with relatively high capital-to-labor ratios will be chosen.

Mutually beneficial trade is thus possible between all countries. As trade is freed, the exchange rate may need to be adjusted to insure that each country is competitive in the products in which it has a comparative advantage. The countries that are endowed heavily with unskilled labor will have a lower standard of living than those endowed heavily with capital and/or highly technical and professional personnel.

2. Intra-North American Trade. Table 4 presents the total trade of the three North American countries, as well as their trade with each other. In both 1972 and 1980, a quarter of total U.S. trade was with Canada and Mexico. With respect to the global U.S. figures, it might be noted that in 1980 the United States imported $\$ 79$ billion worth of fuel (mainly crude petroleum). ${ }^{26}$ In the case of Canada, two thirds of 1980 imports and exports are with the United States, and an insignificant pro-

TABLE 4

\section{INTRA-NORTH AMERICAN Trade (\$BILlions)}

\section{U.S.A.}

Total trade

Trade with Canada

Trade with Mexico

Canada

Total trade

Trade with U.S.

Trade with Mexico

Mexico

Total trade

Trade with U.S.

Trade with Canada

\begin{tabular}{|c|c|}
\hline \multicolumn{2}{|c|}{1972} \\
\hline Exports & Imports \\
\hline 50.0 & 59.0 \\
\hline 12.4 & 15.8 \\
\hline 2.0 & 2.0 \\
\hline
\end{tabular}

\section{1}

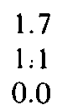

2.7

19.4

13.1

0.1

1.6

0.1

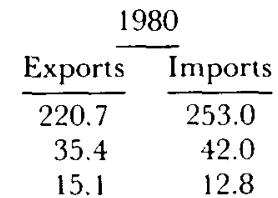

67.5

60.7

$41.1 \quad 41.2$

$0.4 \quad 0.3$

Source: International Monetary Fund, Direction of Trade Yearbook 111, 156, 195 (1981).

25. KREININ, supra note 4 , at ch. 12.

26. GATT, INTERnational Trade 1979/80 app. tables (1981). 
portion with Mexico. Similarly, two thirds of Mexican trade is with the United States, and an insignificant proportion is with Canada.

This pattern reflects the immense relative size of the U.S. economy, the relative factor endowments of the three countries, and the U.S. geographical location between the two other countries. An FTA may somewhat stimulate Canada-Mexico trade. Yet, given the existing trade patterns it is reasonable to consider separately the U.S.-Canada and U.S.-Mexico trade flows.

\section{U.S.-Canada Trade}

1. Composition of Trade. Table 5 shows (first two columns) the 1980 bilateral U.S.-Canada trade flows, classified by main commodity categories. For reference purposes, the table also provides (last four columns) the total trade figures for the two countries.

Both countries are major exporters of food, but primarily to third markets rather than to each other. In fuels and other primary materials, Canada is by far a net exporter to the United States, but these exports already enter the U.S. market

TABLE 5

\section{U.S.-Canada Trade, 1978 (\$Billions)}

\begin{tabular}{|c|c|c|c|c|c|c|c|c|}
\hline \multirow[t]{2}{*}{ Commody Group } & \multicolumn{2}{|c|}{$\begin{array}{l}\text { U.S. Export to } \\
\text { Canada }\end{array}$} & \multicolumn{2}{|c|}{$\begin{array}{l}\text { Canada Export } \\
\text { to the U.S. }\end{array}$} & \multicolumn{2}{|c|}{$\begin{array}{l}\text { Total U.S. } \\
\text { Trade } \\
\end{array}$} & \multicolumn{2}{|c|}{$\begin{array}{c}\text { Total } \\
\text { Canada } \\
\text { Trade }\end{array}$} \\
\hline & & & & & Exp. & Imp. & Exp. & Imp. \\
\hline Primary Products & \multicolumn{2}{|c|}{$5.7(18 \%)$} & \multicolumn{2}{|c|}{$17.0(43 \%)$} & 68.6 & 115.4 & 32.5 & 15.5 \\
\hline Food & 1.7 & $\%$ & 1.8 & $\%$ & 38.8 & 19.1 & 7.8 & 4.3 \\
\hline Raw materials & 0.8 & dist. & 3.7 & dist. & 10.9 & 6.1 & 7.0 & 1.3 \\
\hline Ores and minerals & 0.8 & of & 1.5 & of & 5.8 & 3.6 & 4.7 & 1.9 \\
\hline Fuels & 1.8 & $\mathrm{mfgs}$ & 7.7 & $\mathrm{mfgs}$ & 7.9 & 78.9 & 9.0 & 7.2 \\
\hline Nonferrous metals & 0.6 & exp. & 2.3 & exp. & 5.2 & 7.7 & 4.0 & 0.8 \\
\hline Manufacturers & $25.8(82 \%)$ & $100 \%$ & $22.6(57 \%)$ & $100 \%$ & 138.3 & 118.8 & 30.4 & 41.4 \\
\hline Iron and Steel & 0.5 & $2 \%$ & 1.3 & $6 \%$ & 3.1 & 7.4 & 1.8 & 1.3 \\
\hline Chemicals & 2.5 & 10 & 2.4 & 11 & 24.4 & 9.9 & 4.0 & 3.8 \\
\hline Other semi-mfgs & 1.1 & 4 & 3.9 & 17 & 6.9 & 10.2 & 5.2 & 1.7 \\
\hline Specialized machinery & 5.0 & 19 & 2.0 & 9 & 24.7 & 10.3 & 2.8 & 7.3 \\
\hline $\begin{array}{l}\text { Office and } \\
\text { telecommunication }\end{array}$ & & & & & & & & \\
\hline equipment & 1.3 & 5 & 0.8 & 3 & 13.0 & 9.0 & 1.1 & 2.8 \\
\hline Road motor vehicles* & 7.5 & 29 & 8.2 & 36 & 14.2 & 25.7 & 9.1 & 10.4 \\
\hline Other machinery and trans. & & & & & & & & \\
\hline equipn & 5.3 & 20 & 2.9 & 13 & 36.6 & 16.2 & 4.3 & 7.6 \\
\hline Household appliances & 0.5 & 2 & 0.4 & 2 & 3.0 & 7.5 & 0.7 & 1.5 \\
\hline Textiles and clothing & 0.7 & 3 & 0.1 & 0 & 4.8 & 8.9 & 0.5 & 2.0 \\
\hline Other consumer goods & 1.4 & 6 & 0.6 & 3 & 7.6 & 13.7 & 0.9 & 3.0 \\
\hline Total Trade & 31.5 & & 39.6 & & 209.6 & 238.4 & 63.1 & 57.7 \\
\hline
\end{tabular}

*Subject to the U.S.-Canada automobile pact.

Source: GATT, International. Trade, 1980/81 tables A-17, A-18 (1981). 
duty free. An FTA is unlikely to cause resource reallocation between the primary products and manufacturing sectors. Most resource reallocation will take place within manufacturing.

Because of the nature of the FTA under consideration, special significance attaches to trade in manufactures. Neither country is a major exporter of labor intensive goods such as textiles and clothing. Note, however, that both countries produce these products and their domestic output faces foreign competition from third country sources. Canada is a net exporter to the United States of semimanufactures, and it is a net importer of most other categories. To cast additional light on the structure of bilateral trade, the table also shows the percentage distribution of their manufacturing export to each other. Machinery items loom relatively important in U.S. exports, and road motor vehicles in Canadian exports, reflecting the U.S.-Canada auto agreement.

What is significant about the figures is that there exists a substantial two way trade between the two countries in many industries. This phenomenon is in conformity with the nature of trade among industrial countries; it takes the form of intraindustry rather than interindustry shipments, with each country specializing in specific varieties of goods within each industry. Intraindustry specialization intensifies as trade barriers are brought down.

2. An FTA. There exists a major and detailed study of the economic consequences of a free trade area between Canada and the United States. ${ }^{27}$ It includes, among other things, production cost comparisons for individual industries between the two countries. The study shows that significant benefits would flow to both countries from an FTA between them. The estimated gains are 10 percent of GNP in the case of Canada, and 1 percent of GNP for the United States. Contrary to common belief, there would be no wholesale liquidation of industries in Canada. Specialization would occur within each industry rather than between industries.

Liquidation of some inefficient individual firms is expected, but the remaining firms in each industry would enjoy higher efficiency because of greater specialization, increased competition, and longer production runs made possible by far larger markets. In short, Canadian industry would be reorganized and rationalized as a result of an FTA. While these benefits are smaller in the case of the United States, even here there is likely to be increased efficiency because of greater competitive pressure, and some benefits flowing from larger market size. Lower labor costs in Canada would induce some U.S. firms to set up subsidiaries north of the border or expand existing subsidiaries there. But overall there is likely to be some reduction in the inflow of U.S. investment capital to Canada as trade in goods substitutes partly for capital movement. The Canadian cost advantage is paramount in the areas of the country close to the U.S. industrial heartland, e.g.,

27. WONNACOTT \& WONNACOTT, supra note 1 . 
the Windsor-Toronto-Montreal area. ${ }^{28}$ This implies certain geographical relocation of industry within Canada. Within each industry, there would be a tendency in Canada to drift toward labor intensive activities. But increased efficiency would tend to raise Canadian real wage rates towards the U.S. level.

These eventual gains would not come without significant adjustment costs, although such costs are minimized by the fact that the expansion of trade would occur along intraindustry and not interindustry lines. At the very least, these costs include transfer of resources (including labor) between firms within the same industry and between geographic locations. Such transitional costs would be far greater in Canada than in the United States simply because of the relative importance of trade with the partner country in the total economy. As a consequence it might be necessary to allow a longer transitional period for Canada, perhaps ten years as against five years for the United States, over which the tariff reductions could be staged. Additionally each country would have to set up a sizeable "adjustment assistance fund," with which to help labor and capital in the adjustment process. ${ }^{29}$

The fact that the two countries are already the main trading partners of each other, coupled with the existence of cost differentials in various subindustries between the two countries and with the nature of the outcome outlined above, suggests that trade creation is likely to be far greater than trade diversion. Such trade diversion as may occur is likely to be offset by the expected reduction in production costs in many industries as they are rationalized following the introduction of an FTA.

\section{E. U.S.-Mexico Trade}

1. Structure of Trade. Recent data for U.S.-Mexico trade are not as readily available as those for Canada. Consequently Table 6 was extracted from a U.N. publication pertaining to the United States. In Part A commodities are classified

28. Id.

29. Any national policy that benefits the entire economy is likely to harm certain sectors or segments of the population. It is in the nature of tariff reductions that the benefits are spread over millions of consumers, while the cost (or damage) is concentrated in a few import-competing industries. Sometimes these industries are highly visible and possess considerable political clout.

On both humanitarian and economic grounds, it is desirable for the government to aid these declining industries to adjust to increased volume of imports, attendant upon the tariff reduction. Most industrial countries make provisions for such assistance.

In the United States, trade adjustment assistance is part of the Trade Reform Act of 1974. See KREININ, supra note 4, at ch. 14. It provides assistance to workers and firms heavily impacted by import competition to shift to alternative lines of production. However, there has been considerable abuse of the intent of this legislation. Particularly in autos and steel it often happened that workers received trade adjustment assistance simply as a form of unemployment compensation-waiting to be recalled to their old jobs.

As LDCs (and mainly the so-called New Industrial Countries or NICs) expand their manufacturing exports to the industrial countries, they are interested in blunting political opposition to expanded imports in those countries. In international forums, they therefore press for an elaborate trade adjustment assistance inside the industrial countries.

Among the LDCs themselves, any country undergoing a transition from import substitution to export promotion strategy would require adjustment assistance to the contracting industries during the transition period. 
by the first digit of the Standard International Trade Classification of Commodities (SITC) of which categories 5 through 8 are manufactured goods. While three quarters of U.S. exports to Mexico are comprised of manufactures, only 40 per-

TABLE 6

\section{U.S.-Mexico Trade, 1979 (\$BILlions)}

(A) All Trade (Classified by 1st Digit SITC)

U.S. Import From Mexico

\begin{tabular}{|c|c|c|c|}
\hline Commodity Group & SITC & \$millions & $\%$ of Total \\
\hline Food and live animals & 0 & $\overline{\$ 1,490 \mathrm{~m} .}$ & $17 \%$ \\
\hline Beverages and tobacco & 1 & 82 & 1 \\
\hline Crude metals & 2 & 280 & 3 \\
\hline Mineral fuels & 3 & 3,153 & 35 \\
\hline Oils and fats & 4 & 2 & 0 \\
\hline Chemicals & 5 & 194 & 27 \\
\hline Basic manufactures & 6 & 892 & 10 \\
\hline $\begin{array}{l}\text { Machinery and trans. } \\
\text { equip. }\end{array}$ & $\begin{array}{l}7 \\
8\end{array}$ & $\begin{array}{r}1,893 \\
708\end{array}$ & $\begin{array}{r}21 \\
8\end{array}$ \\
\hline Other manufactures & 8 & 708 & 8 \\
\hline $\begin{array}{l}\text { Special transactions } \\
\text { Total }\end{array}$ & 9 & $\begin{array}{r}289 \\
\$ 8,983\end{array}$ & $\frac{3}{100 \%}$ \\
\hline
\end{tabular}

U.S. Exp. to Mexico

\begin{tabular}{|c|c|}
\hline Smillions & $\%$ of Total \\
\hline$\$ 754 \mathrm{~m}$. & $8 \%$ \\
\hline 4 & 0 \\
\hline 652 & 7 \\
\hline 226 . & 3 \\
\hline 44 & 1 \\
\hline 1,084 & 117 \\
\hline 1,232 & 13 \\
\hline 4,610 & 47 \\
\hline 621 & 6 \\
\hline 436 & 4 \\
\hline$\$ 9,667$ & $\overline{100 \%}$ \\
\hline
\end{tabular}

(B) Manufactures (Categories 5-8 SITC)

\begin{tabular}{|c|c|c|c|c|c|}
\hline Chemicals & 5 & $\$ 194 \mathrm{~m}$. & $5 \%$ & $\$ 1,084 \mathrm{~m}$. & $13 \%$ \\
\hline Basic mfgs. & 6 & 892 & 20 & 1,232 & 16 \\
\hline Leather goods & & 18 & 1 & 16 & 0 \\
\hline Rubber manufactures & & 11 & 0 & 64 & 1 \\
\hline Wood manufactures & & 86 & 2 & 22 & 0 \\
\hline \multicolumn{6}{|l|}{ Paper and } \\
\hline paperboard & & 54 & 1 & 161 & 2 \\
\hline Textiles and yarn & & 65 & 3 & 105 & 2 \\
\hline Minerals & & 109 & 2 & 85 & 1 \\
\hline Iron and steel & & 73 & 1 & 383 & 5 \\
\hline Non-Ferrous metals & & 379 & 8 & 147 & 2 \\
\hline Metal manufactures & & 97 & 2 & 248 & 3 \\
\hline \multicolumn{6}{|l|}{ Machinery and trans. } \\
\hline $\begin{array}{l}\text { equip. } \\
\text { Non-electrical }\end{array}$ & 7 & 1,893 & 52 & 4,610 & 62 \\
\hline machinery & & 995 & 11 & 2,734 & 36 \\
\hline Electrical machinery & & 661 & 35 & 632 & 9 \\
\hline \multicolumn{6}{|l|}{ Transport } \\
\hline $\begin{array}{l}\text { equipment } \\
\text { Other manufactures }\end{array}$ & 8 & $\begin{array}{l}237 \\
708\end{array}$ & $\begin{array}{r}6 \\
23\end{array}$ & $\begin{array}{l}1,244 \\
621\end{array}$ & $\begin{array}{r}11 \\
9\end{array}$ \\
\hline \multicolumn{6}{|l|}{ Plumbing } \\
\hline equipment & & 22 & 0 & 12 & 0 \\
\hline Furniture & & 39 & 1 & 19 & 0 \\
\hline Travel goods & & 28 & 1 & 3 & 0 \\
\hline Clothing & & 224 & 9 & 128 & 2 \\
\hline Footwear & & 47 & 2 & 4 & 0 \\
\hline \multicolumn{6}{|l|}{ Precision } \\
\hline instruments & & 51 & 2 & 194 & 3 \\
\hline Other & & 297 & 8 & 261 & 4 \\
\hline Total Mfgs, 5-8 & & $\$ 3,687$ & $100 \%$ & $\$ 7,547$ & $\overline{100 \%}$ \\
\hline
\end{tabular}

Source: 29:19 Commodity Trade Statistics 1979, U.N. Doc. ST/ESA/STST/SER.D/85-19 (1981). 
cent of U.S. imports from Mexico are in this category. In contrast, food, fuels and metals weigh relatively heavily in U.S imports from Mexico, and many of these enter the U.S. market duty free.

Because the proposed FTA is limited to manufactures, Part B presents the percentage distribution of these products classified by the more detailed commodity breakdown; namely, the three and/or four digit SITC. Chemicals, machinery, transport equipment and instruments weigh heavily in U.S. exports to Mexico. Among U.S. imports, the important items are basic manufactures, electrical machinery, and clothing. The sizeable two-way flow in electrical machinery should not leave the impression that the same types of machines are imported and exported. U.S imports from Mexico are concentrated in telecommunications equipment and transistors, while tractors, civil engineering and textile machinery weigh heavily in U.S. exports to Mexico.

Unlike the case of Canada, a U.S.-Mexico FTA is likely to lead to some measure of interindustry specialization. Although no detailed industry study is available, the previously outlined theory suggests that Mexico would move to specialize in labor intensive as well as material-based products, while the United States would expand the exports of capital intensive goods needed for the Mexican industrialization program. Considering the existing trade barriers, the expansion of trade would probably be of considerable magnitude, yielding sizeable benefits in terms of economic efficiency. But the "pains of adjustment" in terms of economic dislocation would also be severe, suggesting strong political opposition to free trade, and requiring large scale government assistance to labor unions, firms, and indeed whole communities that may be adversely affected. ${ }^{30}$

2. An FTA: Mexican Exports. Consider first U.S. imports and Mexican exports. Half of the total are fuels and primary materials which already enter the United States duty free, or would otherwise remain unaffected by an FTA in manufactured products. When it comes to manufactures, a limited quantity enters the United States under the GSP duty free, or under U.S. tariff item 807.00 subject to very low duty. The remaining items pay a moderate to high tariff.

In particular, labor intensive goods tend to face reasonably stiff rates in the United States. In addition, such imports are subject to a variety of quantitative restrictions that directly limit the quantity that may be imported. For example, international trade in textiles (cottons, woolens, and synthetics) is governed by an international commodity agreement which specifies the quantities that are admitted to each importing country. While an annual growth factor of 6 percent is embodied in the agreement, that factor is drastically curtailed by bilateral agreements (known as "voluntary" export restraints) between the United States and each major supplying country. ${ }^{31}$ Growing imports of other commodities, when

30. See the discussion at note 29 supra.

31. KREININ, supra note 4 , at ch. 15 . 
they reach a proportion that threatens domestic output, generate demands for similar action.

A final feature of the U.S. tariff (as well as that of other industrial countries) on labor intensive products is the escalation of rates by degree of processing. Raw materials enter duty free, intermediate products enter at moderate duty and finished products are subject to high tariff rates. ${ }^{32}$ This constitutes an inducement to exporting countries to ship products in unfinished form, rather than complete the fabrication at home, and export finished manufactures.

All these features of U.S. protection would disappear in an FTA, so one could expect a substantial expansion of manufacturing exports from Mexico to the United States. A large portion of these new trade flows would be in labor intensive products, such as textiles, clothing, leather goods, and lumber products. Since these are products in which Mexico has a comparative advantage, the benefits to the Mexican economy in terms of expanded output, increased employment and improved efficiency are obvious. They are likely to be sizeable.

What of the impact on the United States? Because these tend to be declining industries in the United States to begin with, the adjustment pains to increased imports may be severe. The adjustment process calls for shifting U.S. labor and capital from the import-competing to the export industries. By implication this is a shift of resources from labor intensive to capital intensive industries, which would increase the overall efficiency of the U.S. economy. In all probability the labor intensive industries would not be eliminated altogether. Rather, they would shrink, and at the same time shift production towards specialty products. Once the adjustment process is completed, the efficiency gain to the U.S. economy might be of considerable magnitude.

One mitigating factor in the U.S. adjustment process may be the lessening pressure on, or incentive for, Mexican workers to migrate north of the border. As export opportunities for Mexican industry expand with the opening up of the U.S. export market, more workers would be absorbed in Mexican industry, and wage rates in Mexico may rise somewhat. The inducement for legal or illegal migration would decline. Free commodity movements in an FTA would substitute for labor mobility across the border.

A second factor alleviating the adjustment problem in this country is the prospective expansion of U.S. exports to Mexico. An FTA is a two-way deal. As the machinery and other capital intensive industries expand their imports to Mexico, they should be able (after retraining, relocation, and other adjustments) to absorb the resources released from the labor intensive sector.

3. An FTA: U.S. Exports. Mexico has adopted a mixture of import substitution as well as export-oriented strategies to further its goals as a developing country.

Under an import substitution strategy, the country surrounds itself by a high level of protection, consisting of tariffs, import quotas, exchange controls and the

32. Id. at ch. 13 . 
like. Behind this shelter it expands domestic production to replace imports, at first producing nondurable consumer goods, which are labor intensive in nature and require unsophisticated techniques. Usually, the next step is to turn to the final processing of assembly-type commodities, generating a shift in the composition of imports away from these final products and toward intermediate and capital goods. To do this, the protective structure is escalated by the degree of processing, with final goods more highly protected than intermediate ones.

This strategy, if pursued too far, leads to inefficiencies. The fact that specialization and economies of scale cannot be fully exploited raises costs and prices well above the world market level. First, the protective structure has produced many instances in which the foreign exchange costs of the intermediate imported materials are greater than the foreign exchange value of the final products in which they are embodied. ${ }^{33}$ Second, by restricting the demand for imports, the exchange value of the currency is valued upward artificially as compared with free market conditions, making it more difficult to export primary or manufactured products. Thus the policy discriminates in favor of import-competing industries and against export industries. However, a unit of foreign exchange saved by import substitution costs more in terms of domestic resources than a unit of foreign exchange earned by exports. Third, because the domestic market is usually too small to support an optimal-size plant, excess capacity tends to develop. Thus the widening of the internal market is one main benefit that accrues from regional integration and allocation of industries among the developing countries. However, such steps are usually insufficient and must be supplemented by orienting exports toward the developed world. Fourth, because the system of protection and other policies subsidize the importation of capital goods (at times coupled with artificially high wage rates brought about by union pressure), there is a strong incentive to use capital intensive techniques regardless of the country's factor endowments. Finally, foreign capital that flows into the protected industries often does not generate export earnings but instead aggravates the debt-servicing problem. ${ }^{34}$

An export-oriented strategy on the other hand, involves a change in the system of incentives in favor of exports, minimizing or eliminating the discrimination against them. Countries may even introduce a variety of fiscal incentives to increase exporters' earnings or to reduce exporters' costs (such as reducing or removing duties on imported inputs or reducing the exporters' income taxes). Some countries (such as Mexico and Taiwan) established duty free processing zones into which inputs are imported duty free and from which final goods are exported after processing. ${ }^{35}$ In other cases, tariff rates have been reduced and harmonized, or the currency has been devalued (frequent mini-devaluations in the case of Brazil). ${ }^{36}$ The major effect has been to expand the export of labor intensive manufactured products and to avoid the establishment of insulated, highly inefficient domestic

33. Id.

34. Id.

35. Id. at ch. 17 .

36. E. Suplicy, The Effects of Minidevaluation on the Brazilian Economy (1973) (Ph.D. dissertation at Michigan State University). 
industries. The development experience of countries following export-oriented strategy has tended to be more favorable, in terms of growth rate and expansion of employment, than that of countries developing strictly via import substitution. ${ }^{37}$

Mexico's position appears to be between the two extremes. A measure of import substitution is pursued, resulting in fairly high tariff rates in some industries, and great dispersion in the degree of protection accorded various industries. Although recent systematic data are not available, Table 7 shows the average nominal protection (rates published in the country's tariff schedule) and effective protection (rates imposed on domestic value added, calculated by economists) for several industries. Effective protection on manufacturing industries, the most relevant figure for the purpose at hand, averages 43 percent. In the case of consumer durables it rises above 100 percent, suggesting a degree of import substitution in that sector. In the case of intermediate products, machinery, and transport equipment, the effective rates exceed 40 percent.

\section{TABLE 7}

Nominal and Effective Protection for Major Product Categories in MEXICO, 1960

\begin{tabular}{llcc}
\hline Industry Group & $\begin{array}{c}\text { Nominal } \\
\text { Protection }\end{array}$ & $\begin{array}{c}\text { Effective } \\
\text { Protection }\end{array}$ \\
\hline I & Agriculture, forestry, and fishing & 7 & 3 \\
II & Processed food & 18 & 5 \\
III & Beverages and tobacco & 29 & 48 \\
IV & Mining and tobacco & 4 & -5 \\
V & Construction materials & -4 & 1 \\
VI-A & Intermediate products I & 22 & 42 \\
VI-B & Intermediate products II & 25 & 42 \\
VI & Intermediate products I and II & 24 & 42 \\
VII & Nondurable consumer goods & 25 & 32 \\
VIII & Consumer durables & 49 & 101 \\
IX & Machinery & 29 & 41 \\
X & Transport equipment & 26 & 42 \\
I-X & All industries & 18 & 12 \\
I + IV & Primary production & 6 & 1 \\
II, III, & Manufacturing & & 28 \\
V-X & Manufuring & 25 & 43 \\
VI-X & Manufacturing less food, beverages, tobacco, and construction & & 28 \\
& materials & 28 & 43 \\
\hline
\end{tabular}

Source: B. Balassa, The Structure of Protection in Developing Countries 195 (1971).

In case of an FTA the tariff charged on imports from the United States and Canada would decline gradually, reaching zero at the end of a long transitional period. The United States would be likely to capture a sizeable share of the market in the machinery and durable goods industries, while Mexican resources would move to specialize in products in which Mexico possesses a comparative advantage. The fact that the North American market would open up to these Mexican exports should ease the Mexican adjustment to some extent.

37. McKinnon, Foreign Trade Regimes and Economic Development, 9 J. INT'L ECON. 429 (1979) (summarizing the results of studies of several countries conducted by the National Bureau for Economic Research). 
Economic efficiency in Mexico would benefit from an FTA on both sides of the trade equation. Increased imports would add competitive pressure on Mexican industries, forcing reorganization, rationalization and reallocation of resources. Freer access to export markets would enable Mexico to move towards greater specialization in products in which it possesses a comparative advantage. Since Mexico's advantage is mainly in labor intensive industries, this specialization should increase demand for labor, reduce disguised unemployment, increase earnings, and lessen the pressure to emigrate north of the border. Longer production runs and economies of scale in production and distribution would also follow. Finally, the nonreversible removal of protection would spur both domestic and foreign investments in the Mexican economy.

In sum, an FTA should induce Mexico to follow a policy that would be beneficial even in the absence of an FTA: that of shedding the vestiges of import substitution and replacing it by export promotion. All this contains the seeds of substantial benefits. But the transition period is likely to be painful, necessitating large scale government assistance. ${ }^{38}$

4. Trade Creation and Diversion. For the most part, the increase in U.S. exports to Mexico would replace inefficient domestic production in that country. Such trade creation, coupled with the lower prices the Mexican consumer would enjoy, is clearly beneficial.

In most machinery items and many durable goods, the United States is competitive with alternative sources of supply available to Mexico, especially considering the geographical proximity and the consequent low transport costs. This is apparent from the sharp worldwide expansion of U.S. manufacturing exports in 1979 and 1980 and the rise of the U.S. share in world export markets. ${ }^{39}$ These facts, coupled with the large U.S share in Mexican imports prior to integration, suggest that trade diversion would be much smaller than creation.

Even so, there are reasons to expect at least some trade diversion. First, there are certain products, such as small cars, where the cheapest suppliers are outside North America, and the tariff discrimination would give U.S. producers a competitive edge. This could be partly offset by agreement of the U.S. producers to set up production facilities in Mexico, combining American technology with relatively cheap Mexican labor. The second reason for expecting some trade diversion relates to the energy efficiency of U.S.-made machinery. Considering the past low energy prices in North America relative to those in Europe and Japan, the Europeans and Japanese produce more energy efficient machines. These are preferred by the LDCs. Without the tariff discrimination favoring the United States certain types of capital equipment may have been imported into Mexico from outside North America. This factor is mitigated by the increase in energy efficiency of

38. See the discussion at note 29 supra.

39. The share of the United States in the manufacturing exports of all industrial countries rose from 14.7 percent in 1977 to 15.6 percent in 1980. See GATT, INTERNATIONAL Trade, 1980/81 app. tables (1981). 
U.S.-made machines resulting from the rise in fuel prices, and by the fact that energy is abundant in Mexico.

In the case of Mexican exports to the United States there is reason to expect some trade diversion from other labor abundant countries. But this is mitigated by the fact that imports of labor intensive products into the United States are severely restricted by tariffs as well as quantitative restrictions. Thus the opening up of the U.S. market to Mexican products would displace mainly domestic output (trade creation) rather than exports from third countries. Finally, it might be noted that when a country suffers from large-scale disguised unemployment-as is the case in Mexico-trade diversion is not necessarily harmful.

\section{F. Mexico-Canada Trade}

Trade between Mexico and Canada is of minute proportion. It may be expected to expand when trade barriers are removed, but one is hard put to assess the scope and nature of this expansion. In all likelihood, both trade creation and diversion would occur, but with the former exceeding the latter. This trade would continue to be dwarfed by the U.S.-Mexico trade.

\section{IV \\ SUMMARY}

A North American FTA in manufactured products can yield considerable economic benefits to the three countries involved. It is also likely to be beneficial for worldwide resource allocation. However, all three countries would undergo a painful adjustment process, during which resources would be reallocated both between and within industries to attain greater efficiency and rationalization of industrial production. This dictates a rather lengthy transitional period during which trade liberalization is staged, perhaps longer for Mexico and Canada than for the United States. Large scale government assistance within each country would be required to smooth out the transition. Once completed, however, the benefits would far outweigh the adjustment costs. 
